\title{
The Investigation of the Relationship between Happiness Levels of the Faculty of Sports Sciences and the Levels of Life Satisfaction and Optimism
}

\author{
Kenan $\mathrm{KOÇ}^{1, *}$ \& Osman PEPE ${ }^{1}$ \\ ${ }^{1}$ Faculty of Sports Sciences, Erciyes University, Kayseri, Turkey \\ *Correspondence: Faculty of Sports Sciences, Erciyes University, 38039, Kayseri, Turkey. Tel: 90-505-651-63-13. \\ E-mail: kenankoc@erciyes.edu.tr
}

Received: November 1, 2018

Accepted: November 17, 2018 Online Published: December 10, 2018

doi:10.5430/wje.v8n6p74

URL: https://doi.org/10.5430/wje.v8n6p74

\begin{abstract}
The aim of this study is to investigate the relationship between happiness levels of university students with levels of life satisfaction and optimism. The study sample consists of 318 freshmen, sophomore, junior, and senior students randomly selected from the departments of Physical Education and Sports Teaching, Coaching Education, Sports Management, and Recreation Education of Faculty of Sports Sciences, Erciyes University, Turkey.

Happiness Scale, Satisfaction with Life Scale, and Life Orientation Scale, as well as "Personal Information Form" prepared by the researcher were used as the data collection tools for the purpose of this research.

The data obtained from Personal Information Form, Happiness Scale, Satisfaction with Life Scale, and Life Orientation Scale was analyzed statistically with SPSS 20.0 package program. Personal information and inventory total scores, as well as factor scores for the candidates, are given by determining the frequency (f) and percentage (\%) values. To determine the relationship between the scores obtained from the scales, Pearson Product Moment Correlation Analysis ( $r$ ), and to determine whether obtained scores are predicting each other or not, multiple regression analysis $(\beta)$ were applied.

As a result, happiness was found to have a high-level positive relation with life satisfaction and optimism. Considering the psychological aspects of the curriculum applied to prospective teachers, increasing the level of happiness will contribute to educating more qualified teachers.
\end{abstract}

Keywords: happiness, life satisfaction, optimism, sports sciences, prospective teacher

\section{Introduction}

In every field, the things that people need in a rapidly globalizing world have been renewed and the phenomenon of happiness that humanity has been seeking for centuries has become a much-needed concept as a result of the negative effects caused by different conditions (Karaoğlu et al. 2016; Baysal \& Aka, 2013). In positive psychology, it was focused on the strengths of people to make them live better and happier and was emphasized that the potential of the person should be used at the highest level. As the emphasis on people's strengths increased, concepts such as subjective well-being, psychological well-being, well-being, meaning in life, coping, psychological resilience, hope, and personal development began to take more place in Psychology literature (Csikszentmihalyi, 2005). According to Diener (1984), happiness is a cognitive and affective evaluation of life, and therefore, the individual feeling positive emotions such as joy, pride, confidence, excitement frequently and feeling negative emotions like anger, fear, anxiety, hate less often, as well as getting high satisfaction in various areas of life (i.e., family, work, career, etc.) are evaluated as an indication that they are happy. Human is a whole with its emotion, thought, and behavior. The mood of the individual affects behavior and thoughts. Hence, the well-being of an individual who is happy is expected to increase. For this reason, instead of focusing on the symptoms and pathology, more researches and approaches in line with the age that is focusing on the positive aspects, happiness, well-being, and positive affections of individuals are being prominent. Therefore, interest in positive psychology, which aims to prioritize the strengths of individuals, is increasing (Can, 2018). The fact that being healthy psychologically cannot be explained due to the absence of 
psychological symptoms in individuals makes it increasingly important to investigate happiness and positive well-being from a relational perspective (Gallagher, 2007). It is observed that the variables related to the concept of happiness that the Psychologist want to find out and the effects of these situations on the education system differentiate in time and new variables are added. As a result, it is hoped that conducting research on happiness with life satisfaction and optimism, which are among the important subjects of positive psychology, are important for the disciplines dealing with psychology and that they will contribute to the literature and will draw attention to this neglected field in the education system.

Life satisfaction, which constitutes the cognitive aspect of subjective well-being, is the individual evaluating the life according to their own criteria (Myers \& Diener, 1995). Life satisfaction is the emotional reactions or behavior in their life during their work life, school life, home life, free time, and all other times. Life satisfaction is related to marriage and family life, income level, working conditions, gender, religion, age, social life, race, education level, personality traits, and biological factors (Köker, 1991). In general, life satisfaction is considered in three categories. In the first group, life satisfaction is considered in terms of an external criterion such as well-being, virtue, and holiness. In the second group, what influences people to evaluate their life positively were focused and what influences people's judgments about their lives are emphasized. In the third group, life satisfaction was based on positive emotions ruling over negative emotions during daily life, i.e., was based on the flow of daily life (Arasan, 2010).

On the other hand, the other concept, which is thought to be related to happiness, optimism is the belief people have that they will experience good things in the future and that they can look at the future with confidence (Gillham \& Reivich, 2004). Considering optimism as a cognitive process, Seligman (2000) defined this concept as a positive and flexible thinking structure. Scheier \& Carver (2003) described optimism as being inclined to face positive situations in all aspects of life, regardless of the conditions present. Optimists predict positive results, enter into a situation and expect positive results (Kurz, 2006). Optimists believe that they will achieve positive results in the end, when faced with failure or negativity in their lives. They consider these situations as short-term, controllable, external reasons-related, and exclusive to a particular problem (Çoban \& Demirtaş, 2011). Optimism is linked with academic, military, professional, political, and athletic success, popularity, desire to win, problem-solving ability, a healthy life, and early liberation from trauma (Peterson, 2006). In the researches, it is seen that optimistic individuals show low levels of depression, last a healthy and long life, and recover from illnesses in a shorter time (Lyubomirsky, 2001).

In terms of universities, it is very important to include personal development activities in curriculums to improve their general self-efficacy and professional qualifications (Turan et al. 2016). It is necessary to contribute to the development of personality that includes motivation. Based on these definitions, the aim of the current study is to identify whether there is a relationship between happiness with life satisfaction and optimism or not, if so, in which direction. It is considered that universities will be given higher quality graduates as a result of the addition of their personality traits as well as technical subjects in preparing the curricula in various departments.

\section{Material and Method}

\subsection{Research Model}

The research is conducted in a relational screening model, which can be defined as "the research model aiming to determine the presence and/or level of presence between two and more variables" (Karasar, 2007).

\subsection{Data Collection Tools}

At the application of the surveys to be applied to the students, apart from the researchers, the instructors working at the university have created a healthy evaluation process for them by making necessary explanations in a wide time without rush. Furthermore, to fill the forms in a comfortable situation, suitable materials and environmental conditions were provided for the candidates. Data collection tools used in the research are the Oxford Happiness Scale, Life Orientation (Optimism) Scale, Satisfaction with Life Scale, and Socio-Demographic Information Form.

\subsection{Creating Volunteer Groups}

The research is conducted through working groups. Workgroup of 318 volunteer students randomly selected among 1360 candidates from the departments of Physical Education and Sports Teaching, Coaching Education, Sports Management, and Recreation Education of Faculty of Sport Sciences, Erciyes University, Turkey, in their freshmen, sophomore, junior, and senior (i.e., $1^{\text {st }}, 2^{\text {nd }}, 3^{\text {rd }}$, and $4^{\text {th }}$ ) years during the 2017-2018 academic year constitute the sample of the research. 


\subsection{Socio-Demographic Information Form}

To define the demographic characteristics of the volunteer students, a form consisting of five questions including Gender, Age, Department, Grade, and Grade Point Average (Gpa) have been created by the researcher.

Table 1. The Demographic Profile of the Participants

\begin{tabular}{llll}
\hline & Variable & N & \% \\
\hline \multirow{2}{*}{ Gender } & Male & 194 & 37.7 \\
& Female & 124 & 24.1 \\
Age & $18-21$ & 160 & 31.1 \\
& $22-25$ & 120 & 23.3 \\
& $26-29$ & 38 & 7.4 \\
Department & Physical Education and Sports Teaching & 86 & 16.7 \\
& Coaching Education & 80 & 15.6 \\
& Sports Management & 79 & 15.4 \\
Grade & Recreation Education & 73 & 14.2 \\
& 1 & 75 & 14.6 \\
Grade & 2 & 80 & 15.6 \\
Point & 3 & 79 & 15.4 \\
Average & 4 & 84 & 16.3 \\
\hline
\end{tabular}

\subsection{Oxford Happiness Scale}

Oxford Happiness Scale-Short Form (OHS-S): The scale was developed by Hills and Argyle (2002). OHS-S consisted of 8 items and a .93 $(\mathrm{p}<.001)$ correlation was found between the 29-item-original form. Turkish adaptation of OHS-S was prepared by Doğan \& Çötok (2011). Accordingly, as a result of the exploratory factor analysis, a 7 -item single-factor structure with a self-value of 2.782 explaining $39.74 \%$ of the total variance was obtained. The single-factor structure of OHS-S was examined with confirmatory factor analysis and the goodness of fit indexes were found as $(\chi 2 / \mathrm{df}=2.77$, AGFI $=0.93$, GFI $=0.97$, CFI $=0.95$, NFI $=0.92$, IFI $=0.95$, RMSEA $=0.074)$. Regarding the reliability of the OHS-S, the internal consistency coefficient was calculated as .74 and the test-retest reliability coefficient as .85 .

\subsection{Life Orientation (Optimism) Scale}

Life Orientation Test: The Life Orientation Test, developed by Scheier \& Carver (1987) and adapted into Turkish by Aydın \& Tezer (1991), consists of 12 items and each item requires the participant to state one of these 5 degree responses: Strongly disagree (0), Disagree (1), Neutral (2), Agree (3), Strongly Agree (4). Positive (optimistic) or negative (pessimistic) expressions are presented to the subjects in each item of the test and they are asked to mark the appropriate option for them. Among these items, 4 of them were scored positively and 4 were scored negatively. In addition, there are 4 neutral/filler items that are not scored in any direction on the scale. The lowest score is 0 and the highest score is 32 . The high score obtained from the scale indicates that there is optimism or a positive point of view towards life, and a low point indicates pessimism or a negative point of view towards life. The reliability of the scale was examined with the test-retest method, and the test was applied to 97 university students twice with four weeks intervals and the reliability coefficient was calculated as $.77(\mathrm{p}<.001)$. In the validity study, the Beck Depression Inventory was used as a benchmark to measure the correlation between the two scale scores. Two scales were applied to two different university student groups consisting of 50 people and 97 people, and the correlation coefficients for the groups were calculated as $-.56(\mathrm{p}<.001)$ and $-.45(\mathrm{p}<.001)$, respectively. 


\subsection{Satisfaction with Life Scale}

In 1985, Diener et al. (2000) developed the Satisfaction with Life Scale (SWLS). It was developed to determine the satisfaction of individuals from their lives. The scale consists of 5 items in the Likert type with 7 degrees (1: strongly disagree - 7: Strongly agree). In the original study, Diener et al. found the reliability of the scale as Alpha $=.87$ and criterion-dependent validity as .82. The scale was adapted to Turkish by Yetim (1993). The reliability of the scale $($ Alpha $=.86)$ and test-retest reliability were found as .73 in this study. The highest score that can be taken from the Satisfaction with Life Scale is 35 and the lowest score is 5 . Low scores on the scale indicate that life satisfaction is low.

\section{Results}

Table 2. Descriptive Statistics of Scale Scores of Participants

\begin{tabular}{lllll}
\hline & $\mathbf{N}$ & Minimum & Maximum & $\mathbf{X} \pm$ SD \\
\hline Happiness & 318 & 65.00 & 164.00 & $112.27 \pm 17.74$ \\
Optimism & 318 & 17.00 & 31.00 & $29.60 \pm 4.13$ \\
Life Satisfaction & 318 & 5.00 & 35.00 & $21.83 \pm 7.21$ \\
\hline
\end{tabular}

When Table 2 is examined, the averages of the happiness, optimism, and life satisfaction are calculated as 112.2, 29.60 , and 21.83 , respectively.

Table 3. Correlation coefficients between happiness levels with optimism levels and life satisfaction levels $(n=318)$ of students

\begin{tabular}{|c|c|c|c|c|}
\hline & & Happiness & Optimism & Life Satisfaction \\
\hline \multirow{3}{*}{ Happiness } & $\mathrm{r}$ & 1 & & \\
\hline & $\mathrm{p}$ & & & \\
\hline & $\mathrm{N}$ & 318 & & \\
\hline \multirow{3}{*}{ Optimism } & $\mathrm{r}$ & $.410^{* *}$ & 1 & \\
\hline & $\mathrm{p}$ & .000 & & \\
\hline & $\mathrm{N}$ & 318 & 318 & \\
\hline \multirow{3}{*}{ Life Satisfaction } & $\mathrm{r}$ & $.518^{* *}$ & $.218^{* *}$ & 1 \\
\hline & $\mathrm{p}$ & .000 & .000 & \\
\hline & $\mathrm{N}$ & 318 & 318 & 318 \\
\hline
\end{tabular}

$* * \mathrm{p}<0.001$

When Table 3 is examined, while a high-level positive correlation $(r=.410, p<.001)$ between happiness and optimism was found, a high-level positive correlation $(\mathrm{r}=.518, \mathrm{p}<.001)$ was also calculated between happiness and life satisfaction.

Table 4. Regression Results for Happiness Levels Predicting the Optimism Levels of Students

\begin{tabular}{|c|c|c|c|c|c|c|c|c|}
\hline & & $\beta$ & $t$ & $p$ & $R$ & $\boldsymbol{R}^{2}$ & $\mathbf{F}$ & $\mathbf{P}$ \\
\hline Happiness & Optimism & .410 & 7.991 & $.000 * *$ & .410 & .168 & 63.849 & $.000 * *$ \\
\hline
\end{tabular}

$\mathrm{F}(1,316)$

Table 4 presents a significant relationship between Happiness and Optimism $(\mathrm{R}=.410, \mathrm{R} 2=.168 ; \mathrm{p}<.001)$. When $\mathrm{t}$-test results for the significance of the regression coefficient were examined, it was observed that $(\mathrm{t}=7.991, \mathrm{p}$ $=.000)$ Happiness predicted Optimism and explained $16.8 \%$ of total variance $(\mathrm{F} 1.316=63.849, \mathrm{p}<.001)$. 


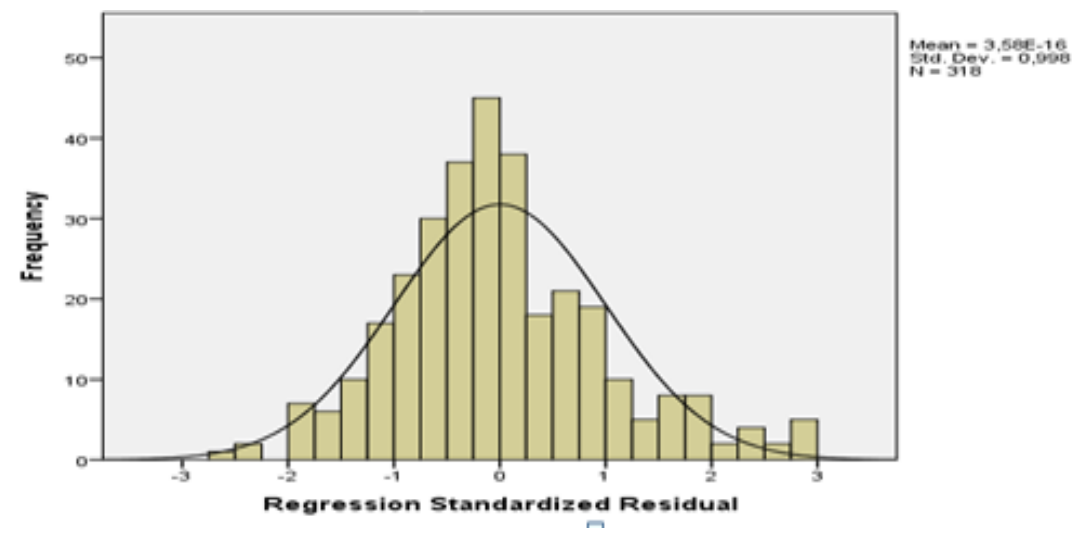

Chart 1. Happiness and Life Satisfaction Histogram

Table 5. Regression Results for Happiness Levels Predicting the Life Satisfaction Levels of Students

\begin{tabular}{|c|c|c|c|c|c|c|c|c|}
\hline & & $\beta$ & $\mathbf{t}$ & $p$ & $R$ & $R^{2}$ & $\mathbf{F}$ & $\mathbf{P}$ \\
\hline Happiness & I ife Saticfoction & 518 & 10760 & $000 * *$ & .516 & .268 & 115.978 & $.000 * *$ \\
\hline
\end{tabular}

$\mathrm{F}(1,316)$

Table 5 presents a significant relationship between Happiness and Life Satisfaction $(\mathrm{R}=.516, \mathrm{R} 2=.268 ; \mathrm{p}<.001)$. When $\mathrm{t}$-test results for the significance of the regression coefficient were examined, it was observed that $(\mathrm{t}=7.991, \mathrm{p}$ $=.000)$ Happiness predicted Life Satisfaction and explained $16.8 \%$ of total variance $(\mathrm{F} 1.316=115.978, \mathrm{p}<.001)$.

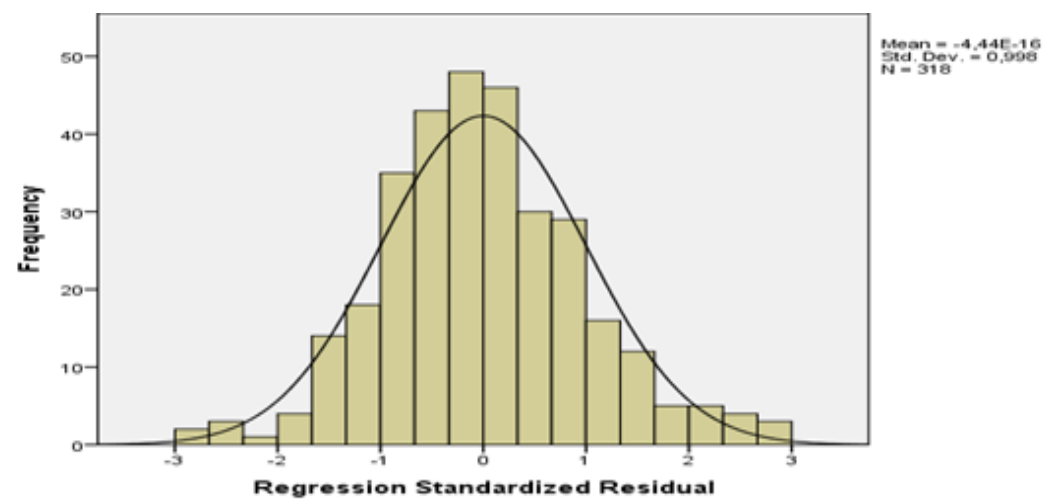

Chart 2. Happiness and Optimism Histogram

\section{Discussion and Conclusion}

According to the data of the current study, there was a high-level positive correlation between happiness and optimism. At the same time, happiness predicts optimism by $16.8 \%$. On the other hand, there was a high-level positive correlation between happiness and life satisfaction as well. When we look at the model, happiness predicts life satisfaction by $26.8 \%$. When the studies in the literature are examined below results are reached.

In their study with 100 people who have professional careers between the ages of 35-40, Raikkönen, Matthews \& Flory (1999), observed that the blood pressure is lower in the pessimistic and anxious individuals compared to the optimists, and higher than the anxious people, and they possess less positive and more intense negative emotions. Optimists show high blood pressure like pessimistic or anxious individuals when they experience negative emotions. In the study of Puskar et al. (1999) conducted on 624 high school students living in rural areas, they investigated the relationship between depressive symptoms, struggling, anger, and life events with optimism, and female students were found to have lower levels of optimism than men, although the difference was not statistically significant. Students with high-level of optimism did not have lower symptoms of anger and depression. In their research on 
anxiety, success, optimism, and pessimism on 400 university students, al-Anzi (2005) found a positive relationship between academic achievement and optimism and a negative relationship between academic achievement and pessimism. Lyubomirsky (2007) depicts happiness as a pride of a combination of joys that are obtained through life in wealth and comfort or pleasure and satisfaction. In another opinion, Diener (1984) describes happiness as getting maximum satisfaction from life by having positive feelings often and negative feelings less. When the definitions are evaluated, three important points are noteworthy. First of all, how long the positive feelings are experienced, then how much negative feelings are experienced, and finally the degree of life satisfaction are prominent. Negative and positive feelings are the emotional part of happiness while the other part, i.e., the mental dimension, is completed with life satisfaction (Çeçen, 2007; Diener, 1984). Hence, happiness is a matter of reducing negative feelings and strengthening a positive point of view, in other words, viewing life events with a positive perception. Together with the increase in the sense of happiness, people's view of life will be more flexible and tolerant and the feelings of optimism will increase.

In their study, Gümüşbaş (2008) investigated the secondary school students on combating stress and its effect on life satisfaction. The study was conducted in İzmir, Turkey with a total of 30 students in $6^{\text {th }}, 7^{\text {th }}$, and $8^{\text {th }}$ grades composed of 13 girls and 17 boys. Experimental and control groups were formed in the study. As a result of the research, significant differences were observed in the life satisfaction of experimental and control groups. Pekel et al. (2015) stated that people who have high life satisfaction levels exhibit healthy behaviors and experience a better quality education life. Gilman \& Huebner (2006) examined the characteristics of adolescents with high life satisfaction. As life satisfaction increases, self-esteem, hope, Gpa, attitude towards school increases positively; while anxiety, external locus of control, and depression are decreasing. Nonetheless, being happy does not only make the person feel good but also have other positive returns on the person's life. It is thought that people who are happy will enjoy life, will be healthier, have stronger social relations, and thus will have an increased life satisfaction.

Gülcan (2014) reported a significant positive correlation between happiness, optimism, and life satisfaction in a study of 394 (225 female/169 male) young adults studying at the university. Demir (2017) also found that there are significant relationships between happiness, life satisfaction, optimism, and habitat in their study with a group of 687 volunteer prospective teachers. Şahin (2015) found that a medium level positive correlation was found between optimism and happiness, according to the findings of the study on 532 university students.

As mentioned in the above studies, it is seen that there are positive relations between happiness, life satisfaction, and optimism, but also in some researches, it was seen that their levels change according to different variables. The findings of the current study are in parallel with the literature. As a result, it was found that happiness was related to optimism and life satisfaction and happiness predicted both variables. In order to increase academic success, it was important to organize programs that would increase students' happiness levels while preparing educational environments.

\section{Suggestions}

- Evaluations can be made by considering other concepts which are valuable in terms of positive psychology as well.

- This study has been done quantitatively and qualitative studies can be done to reach more detailed data.

- With the idea that happiness increases optimism and life satisfaction; educational seminars -individually or by groups- that would increase happiness or psychological consulting can be done in counseling services of primary, secondary, and higher education institutions.

- In-service trainings can be provided by observing the situation of young adults who are fresh graduates from university.

\section{References}

Arasan, B. N. A. (2010). Akademisyenlerde Yaşam Doyumu, Işs Doyumu Ve Mesleki Tükenmişlik Düzeylerinin Belirlenmesine Yönelik Bir Araştırma. Yayınlanmamış Yüksek Lisans Tezi, Uşak Üniversitesi Sosyal Bilimler Enstitüsü, Uşak.

Arthur J. Gallagher Risk Management Services, Inc. (2009). Road to Implementation ERM for Colleges and Universities.

Baysal, S., \& Aka, İ.Ç. (2013). Bir Pazarlama Stratejisi Olarak Mutluluk Temasının Markalar Tarafından 
Kullanılması: Mutluluk Temelli Pazarlama Üzerine Bir Araştırma. Sosyal ve Beşeri Bilimler Dergisi, 5(1), 84-93.

Can M. (2018). Üniversite Öğrencilerinin Mutluluk, Psikolojik Sağlamlık Ve Öz Yeterlik Düzeylerinin İncelenmesi Yayınlanmamış Yüksek Lisans Tezi İstanbul Aydın Üniversitesi, Sosyla Bilimler Enstitüsü.

Csikszentmihalyi, M.(2005). Akış. Mutluluk bilimi. İstanbul: HYB Yayıncılık.

Çeçen, R. A. (2007). Üniversite Öğrencilerinin Cinsiyet ve Yaşam Doyumu Düzeylerine Göre Sosyal ve Duygusal Yalnızlık Düzeylerinin İncelenmesi. Mersin Üniversitesi Eğitim Fakültesi Dergisi, 3(2), 180-190.

Çoban, D., \& Demirtaş H. (2011). Okulların Akademik İyimserlik Düzeyi ile Öğretmenlerin Örgütsel bağlllı̆̆ arasındaki ilişki. Kuram ve Uygulamada Eğitim Yönetimi, 17(3), 317-348.

Demir, R. (2017). Öğretmen Adaylarının Mutluluk, İyimserlik, Yaşam Alanı ve Yaşam Doyumlarının İncelenmesi, Yayınlanmamış Yüksek Lisans Tezi, Gaziantep Üniversitesi, Eğitim Bilimleri Enstitüsü.

Diener, E. (1984). Subjective Well-Being. Psychological Bulletin, 75(3), 542-575. https://doi.org/10.1037/0033-2909.95.3.542

Diener, E., Emmons, R. A., Larsen, R. J., \& Griffin, S. (1985). The satisfaction with life scale. Journal of Personality Assessment, 49(1), 71-75. https://doi.org/10.1207/s15327752jpa4901_13

El-Anzi \& Freih Owayed. (2005). Akademic Achievemsent And Its Relationship With Anxiety, Self-Esteem, Optimism, And Pessimism, İn Kuwaiti Students. Social Behavior And Personality, 33(1), 95-104. https://doi.org/10.2224/sbp.2005.33.1.95

Gallagher MW., \& Lopez SJ. (2007). Curiosity and well-being. Journal of Positive Psychology, 2, 236-248. https://doi.org/10.1080/17439760701552345

Gillham, J., \& Reivich, K. (2004). Cultivating optimism in childhood and adolescence. The Annals of the American Academy of Political and Social Science, 591(1), 146-163. https://doi.org/10.1177/0002716203260095

Gilman, R., \& Huebner, E. S. (2006). Characteristics Of Adolescents Who Report Very High Life Satisfaction. Journal of Youth And Adolescence, 35, 311-319. https://doi.org/10.1007/s10964-006-9036-7

Gülcan A. (2014). Genç Yetişkinlerde İyimserliğin Mutluluk Ve Yaşam Doyumu Üzerindeki Etkisinin İncelenmesi, Yayınlanmamış Yüksek Lisans Tezi, Fatih Üniversitesi, Sosyal Bilimler Enstitüsü.

Gümüşbaş, B (2008). Stresle Başa Çıkma Yolları Eğitim Programının İlköğretim 2. Kademe Öğrencilerinin Stresle Başa Çıkma Yöntemleri ve Yaşam Doyumu Üzerindeki Etkisinin İncelenmesi. Yüksek Lisans Tezi İzmir.

Hills, P., \& Argyle, M. (2002). The Oxford Happiness Questionnaire: a compact scale for the measurement of psychological well-being. Personality and Individual Differences, 33(7), 1073-1082. https://doi.org/10.1016/S0191-8869(01)00213-6

Karaoğlu B., Turan M. B., \& Pepe O. (2016) Beden Eğitimi Ve Spor Yüksekokulu Öğrencilerinin Yaratıcıllk Düzeyleri İle Duygusal Zekâ Seviyelerinin İncelenmesi. Gaziantep Üniversitesi Spor Bilimleri Dergisi, 1-2.

Karasar, N. (2007). Bilimsel Araştırma Yöntemi (17.Baskı), Ankara, Nobel Yayın Dağıtım: 49-53.

Köker, S. (1991). Normal ve sorunlu ergenlerin yaşam doyumu düzeyinin karşılaştırılması. Yayınlanmamış Yüksek Lisans Tezi, Ankara Üniversitesi Sosyal Bilimler Enstitüsü, Ankara.

Kurz, N. M. (2006). The relationship between teachers sense of academic optimism and commitment to the profession. Unpublished doctoral dissertation, University of Ohio State, USA.

Lyubomirsky, S. (2007). The How Of Happiness: A Scientific Approach To Getting The Life You Want. New York: The Penguin Press.

Lyubommirsky, S. (2001). Why are some people happier than others? American Journal of Psychology, 56(3), 239-249. https://doi.org/10.1037/0003-066X.56.3.239

Myers DG., \& Diener E. (1995). Who is happy? Psychological Science, 6, 10-19. https://doi.org/10.1111/j.1467-9280.1995.tb00298.x

Pekel A., Turan M. B., Pepe O., \& Bahadır Z. (2016). The Relationship With Life Satisfaction Between Health Promoting Behaviours Of Special Education Teachers (Kayseri City Sample). International Journal Of Science Culture And Sport. 
Peterson, C. (2006). A primer in positive psychology. Oxford University Press.

Puskar, Kathryn R., Sereika, Susan M., Lamb, Jacline., T. M, \& Kathleen. M. T. (1999). Optimism And Its Relationship To Depression. Coping,.Anger, And Life Events İn Rural Adolescents. Issues İn Mental Health Nursing, 20, 115-130. https://doi.org/10.1080/016128499248709

Raikkönen, Katri., Matthews, Karen A., Flory, Janine D., Owens, Jane F., Gump \& Brooks B. (1999). Effects Of Optimism, Pesimism, And Trait Anxiety On Ambulatory Blood Presure And Mood During Everyday Life. Journal Of Personality And Social Psychology, 76(1), 104-113. https://doi.org/10.1037/0022-3514.76.1.104

Scheier, M. F., \& Carver, C. S. (1987). Dispositional optimism and physical well-being: The influence of generalized outcome expectancies on health. Journal of Personality, 55(2), 169-210. https://doi.org/10.1111/j.1467-6494.1987.tb00434.x

Scheier, M. F., \& Carver, C. S. (2003). Self-regulatory processes and responses to health threats: effects of optimism on well-being. In J. Suls \& K. Wallston (Eds.), Social Psychological Foundations of health, (Pp. 395-428). Malden, Ma: Blackwell. https://doi.org/10.1002/9780470753552.ch15

Seligman, M., \& Csikszentmihalyi, M. (2000). Positive Psychology An İntroduction. American Psychological Association, 55(1), 5-14. https://doi.org/10.1037/0003-066X.55.1.5

Şahin Y. (2015). Üniversite Öğrencilerinin Mutluluk İyimserlik ve Özgecilik Düzeylerinin İncelenmesi, Yayınlanmamış Yüksek Lisans Tezi, Gazi Osman Paşa Üniversitesi, Eğitim Bilimleri Enstitüsü.

Turan M. B., Karaoğlu B., Kaynak K., \& Pepe O. (2016). Özel Yetenek Sınavlarına Giren Adayların Genel Öz Yeterlilik Düzeylerinin Bazı Değişkenlere Göre İncelenmesi. Spor Bilimleri Araştırmaları Dergisi, 1(1), 17-26. https://doi.org/10.25307/jssr.274319 